\title{
Liming and application of nitrogen, phosphorus, potassium, and boron on a young plantation of chestnut
}

\author{
Margarida ARROBAS $^{1, *}$, Sandra AFONSO ${ }^{1}$, Isabel Q. FERREIRA ${ }^{1}$, \\ José MOUTINHO-PEREIRA ${ }^{2}$, Carlos M. CORREIA ${ }^{2}$, M. Ângelo RODRIGUES ${ }^{1}$ \\ ${ }^{1}$ Mountain Research Centre, Polytechnic Institute of Bragança, Bragança, Portugal \\ ${ }^{2}$ Centre for the Research and Technology of Agro-Environmental and Biological Sciences, University of Trás-os-Montes e Alto Douro, \\ Vila Real, Portugal
}

Received: 18.05 .2017

- Accepted/Published Online: 25.08.2017

$\bullet$

Final Version: 18.12.2017

\begin{abstract}
European chestnut is the most important cash crop in the highlands of NE Portugal. However, limited data on cropping technique are available to help farmers make decisions. This work is motivated by the lack of data related to chestnut response to fertilizer application. It reports results from a field fertilization trial consisting of the application of a combination of lime (L), nitrogen $(\mathrm{N})$, phosphorus (P), potassium (K), and boron (B), namely LNPKB, NPKB, -NPKB, N-PKB, NP-KB, and NPK-B. Seedlings of chestnut were planted in June 2013 and grown for four growing seasons. Plant height, trunk diameter, and pruning wood were assessed every year and used as indicators of tree crop growth. Elemental leaf analysis and other tools [SPAD-502 chlorophyll meter; Field Scout CM 1000 NDVI (normalized difference vegetation index) meter, and the OS-30p+ fluorometer] were used to assess plant nutritional stresses. In January 2017 soil samples were collected at three depths $(0-5,5-10$, and $10-20 \mathrm{~cm})$ to determine several soil fertility parameters. The nonapplication of $\mathrm{K}$ and $\mathrm{B}$ reduced the tree crop growth and pruning residues. Leaf analysis revealed leaf $\mathrm{K}$ and $\mathrm{B}$ concentrations respectively in the NP-KB and NPK-B treatments to be in the deficient range previously established for chestnut. SPAD readings and NDVI detected the reduced availability of $\mathrm{N}$ associated with the -NPKB treatment but not the reduced plant growth associated with NP-KB or NPK-B treatments. The dark adaptation protocols of $\mathrm{F}_{\mathrm{V}} / \mathrm{F}_{\mathrm{M}}, \mathrm{F}_{\mathrm{V}} / \mathrm{F}_{0}$, and OJIP measurements performed with the OS-30p+ fluorometer failed to diagnose the nutrient stresses detected by leaf analysis or the reduction in plant growth.
\end{abstract}

Key words: Castanea sativa, leaf analysis, soil testing, SPAD readings, normalized difference vegetation index, chlorophyll fluorescence

\section{Introduction}

Many species of the genus Castanea are grown in several parts of the world for timber and/or edible nut production (Portela et al., 2007). In Portugal, the European chestnut (Castanea sativa Mill.) has been grown for centuries for both wood and fruit. While wood production is declining due to the fall in price and the poor phytosanitary conditions of chestnut stands, the production of fruit is expanding in the mountainous areas of northern Portugal. Although countless trees are being decimated by chestnut blight (Cryphonectria parasitica (Murrill) Barr.) and root rot (Phytophthora cinnamomi Rand) diseases, in particular the latter (Maurel et al., 2001; Gouveia et al., 2005), the high prices of nuts have stimulated the plantation of new orchards. Farmers try to take advantage of the current good prices of the nut and are planting new orchards in the hope that in the long term a solution to the death of the trees will be found.
Cropping practices are, however, currently in the process of change. In the past, huge isolated trees and orchards of low tree density dominated the landscape. Nowadays, orchards are established with many more plants per hectare (trees spaced at $8 \times 8 \mathrm{~m}$ or less) and the cropping system is intensified, with regular pruning, chemical fertilization, and mechanical harvesting, stimulated by the expectation of a high profit that the price of the nut may provide. However, there are limited scientific data on chestnut management, in particular in the field of mineral nutrition and crop fertilization (Portela et al., 2007). In the past, this species was not fertilized, the soil only being amended when farmyard manure was available. Regular application of mineral fertilizers is a recent introduction. Consequently, as far as we know, there are no field studies on NPK fertilization. However, studies done with young potted plants have shown that the crop responds to the application of mineral nutrients (El Kohen et al., 1992;

*Correspondence: marrobas@ipb.pt 
Laroche et al., 1997), and therefore it is expected that a positive response to fertilization may also occur in the field. Pérez-Cruzado et al. (2011) used wood-bark ash, a product rich in $\mathrm{Ca}, \mathrm{K}, \mathrm{Mg}$, and to a lesser extent $\mathrm{P}$, as a fertilizer in a young chestnut orchard. They recorded an increase in the diameter and height of the trees and also an improvement in the nutritional status of the plants in terms of $\mathrm{K}, \mathrm{Ca}$, and $\mathrm{Mg}$.

Studies conducted in northern Portugal showed that chestnut may display symptoms of B deficiency (Portela and Louzada, 2012; Portela et al., 2015b) and responds to the application of the nutrient as a fertilizer (Portela et al., 2011, 2015a), as do other important crops in the region, such as olive (Arrobas et al., 2010; Rodrigues et al., 2011). In the north of Portugal, symptoms of $\mathrm{Mg}$ deficiency also seem to occur with some frequency, at least in some lithological formations (Portela et al., 2003, 2010). The importance of $\mathrm{Mg}$ in chestnut was also reported by AfifKhouri et al. (2011), who identified soil Mg as one of the most important indicators of site productivity in a study from northwestern Spain.

This work is motivated by the lack of data related to chestnut response to fertilizer application. The main goal is to study the response of chestnut to the application of lime, $\mathrm{N}, \mathrm{P}, \mathrm{K}$, or $\mathrm{B}$, being the main components of the regional fertilizer recommendation programs for other crops. Taking into account that the soils in the region are acidic, there is a chronic shortage of $\mathrm{B}$ in most regional soils, and $\mathrm{N}, \mathrm{P}$, and $\mathrm{K}$ are macronutrients regularly applied to any crop. The formulated hypothesis is that chestnut, as in all crops in general, responds to the increased availability of nutrients in the soil as long as they are found in quantities insufficient to fulfill the plants' requirements. The results are expected to be important in establishing adequate fertilization recommendation programs for the crop, with the aims of enhancing the tree performance and reducing the risk of environmental damage through the use of inappropriate rates or combinations of nutrients.

\section{Materials and methods}

\subsection{Site characterization}

The study was carried out in Bragança, NE Portugal (41.77898; -6.81612). The region of Bragança benefits from a Mediterranean-type climate, somewhat influenced by the Atlantic regime. The average annual air temperature and annual precipitation in the period of 1971-2000 were 12.3 ${ }^{\circ} \mathrm{C}$ and $758 \mathrm{~mm}$, respectively. Mean monthly temperature and precipitation recorded during the experimental period at the meteorological station of Qta de Santa Apolónia in Bragança are presented in Figure 1. The field trial was established in a Leptosol originating from a bedrock of schist. Some important soil properties determined shortly before the trial started, from a soil sample taken at 0-20 $\mathrm{cm}$ soil depth, are presented in Table 1.

\subsection{Experimental design and orchard management}

The experiment was arranged in a randomized block design with three replicates. The six fertilizer treatments were: 1) lime plus $\mathrm{N}, \mathrm{P}, \mathrm{K}$, and $\mathrm{B}(\mathrm{LNPKB}) ; 2) \mathrm{N}, \mathrm{P}, \mathrm{K}$, and $\mathrm{B}$ (NPKB); 3) P, K, and B (-NPKB); 4) N, K, and B (N-PKB); 5) N, P, and B (NP-KB); and 6) N, P, and K (NPK-B). Each experimental unit was composed of a group of 10 trees. The plants within each experimental unit were planted at $1.5 \mathrm{~m}$ in the row and $9 \mathrm{~m}$ between rows. For each treatment three replicates (three groups of 10 plants) were included. The total area of each experimental unit was $135 \mathrm{~m}^{2}$. However, the fertilizers were applied in a reduced area of $60 \mathrm{~m}^{2}$ per experimental unit ( $15 \mathrm{~m}$ of the row and $4 \mathrm{~m}$ laterally, 2

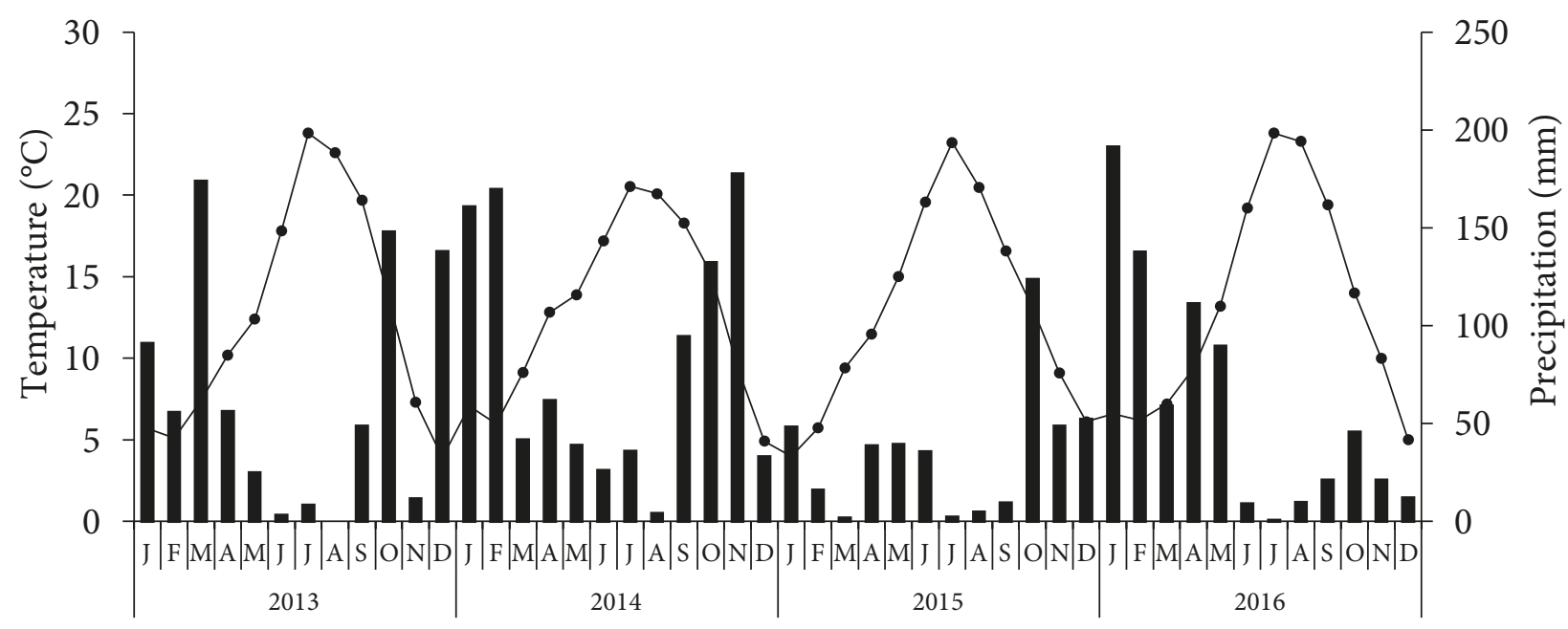

Figure 1. Average monthly temperature and accumulated precipitation recorded during the experimental period (2013-2016) at the weather station of Qta de Sta Apolónia, Bragança. 
Table 1. Selected properties of the soil sampled shortly before the trials started at a depth of $0-20 \mathrm{~cm}$.

\begin{tabular}{|l|l|l|l|}
\hline Soil properties & & Soil properties & \\
\hline Clay (\%) & 11.8 & Extractable $\mathrm{P}\left(\mathrm{mg} \mathrm{kg}^{-1}\right)^{\mathrm{d}}$ & 15.48 \\
\hline Silt (\%) & 26.3 & Extractable $\mathrm{K}\left(\mathrm{mg} \mathrm{kg}^{-1}\right)^{\mathrm{d}}$ & 86.00 \\
\hline Sand (\%) & 61.9 & Exchangeable bases & \\
\hline Texture (USDA) & Loam & $\mathrm{Ca}\left(\mathrm{cmol}_{\mathrm{c}} \mathrm{kg}^{-1}\right)$ & 5.69 \\
\hline $\mathrm{pH}_{\mathrm{H} 2 \mathrm{O}}$ & 5.50 & $\mathrm{Mg}\left(\mathrm{cmol}_{\mathrm{c}} \mathrm{kg}^{-1}\right)$ & 2.07 \\
\hline $\mathrm{pH}_{\mathrm{KCl}}$ & 4.30 & $\mathrm{~K}\left(\mathrm{cmol}_{\mathrm{c}} \mathrm{kg}^{-1}\right)$ & 0.23 \\
\hline Oxidizable C $\left(\mathrm{g} \mathrm{kg}^{-1}\right)^{\mathrm{a}}$ & 0.87 & $\mathrm{Na}\left(\mathrm{cmol}_{\mathrm{c}} \mathrm{kg}^{-1}\right)$ & 0.36 \\
\hline Total organic C $\left(\mathrm{g} \mathrm{kg}^{-1}\right)^{\mathrm{b}}$ & 2.34 & Exchangeable acidity $\left(\mathrm{cmol}_{\mathrm{c}} \mathrm{kg}^{-1}\right)$ & 0.10 \\
\hline Extractable B $\left(\mathrm{mg} \mathrm{kg}^{-1}\right)^{\mathrm{c}}$ & 0.25 & Exchangeable Al $\left(\mathrm{cmol}_{\mathrm{c}} \mathrm{kg}^{-1}\right)$ & 0.10 \\
\hline
\end{tabular}

${ }^{\mathrm{a}}$ Walkley-Black; ${ }^{\mathrm{b}}$ incineration; ${ }^{\mathrm{c}}$ azomethine $\mathrm{H}$; ${ }^{\mathrm{d}}$ ammonium-lactate; ${ }^{\mathrm{e}}$ ammonium-acetate, $\mathrm{pH} 7$.

$\mathrm{m}$ on each side of the planting line). Lime was applied only once at a rate of $2000 \mathrm{~kg} \mathrm{ha}^{-1}$ considering only the $60 \mathrm{~m}^{2}$ mentioned above, and before the establishment of the crop. A product with $80 \% \mathrm{CaCO}_{3}$ and $5 \% \mathrm{MgCO}_{3}$ was used. Phosphorus and $\mathrm{K}$ were applied annually in early spring at the rate of $100 \mathrm{~kg} \mathrm{ha}^{-1}$ (expressed as $\mathrm{P}_{2} \mathrm{O}_{5}$ and $\left.\mathrm{K}_{2} \mathrm{O}\right)$, as $18 \%$ superphosphate $\left(\mathrm{P}_{2} \mathrm{O}_{5}\right)$ and $60 \%$ potassium chloride $\left(\mathrm{K}_{2} \mathrm{O}\right)$. Nitrogen was also applied every year in early spring at a rate of $30 \mathrm{~kg} \mathrm{~N} \mathrm{ha}^{-1}$ as ammonium nitrate $20.5 \% \mathrm{~N}\left(50 \% \mathrm{NH}_{4}^{+}, 50 \% \mathrm{NO}_{3}^{-}\right)$. Boron was also applied annually at a rate of $3 \mathrm{~kg} \mathrm{ha}^{-1}$ of $\mathrm{B}$ as borax (11\% B). In 2016 the rate of $B$ was reduced to $2 \mathrm{~kg} \mathrm{ha}^{-1}$.

The experimental field was established from seedlings sown on 23 March 2013 and transplanted on 5 June 2013. On the planting date the seedlings were between 15 and $25 \mathrm{~cm}$ in height and were randomly distributed to all the plots. The soil was prepared with a moldboard plow and a chisel to a depth of $30 \mathrm{~cm}$. The fertilizers applied in the first year were incorporated in the top $15 \mathrm{~cm}$ with a cultivator in a complementary soil tillage operation. The plants were planted after opening a furrow with a moldboard plow complemented manually with hoes. The root system was buried to a depth of $15 \mathrm{~cm}$. During the first growing season, from July, the plants were watered to reduce mortality. Biweekly, 7 to $8 \mathrm{~L}$ of water was applied in a furrow opened near the base of the young plants. In the following years the ground was not tilled again. The weeds were controlled by using a nonselective postemergence herbicide (glyphosate-based, $360 \mathrm{~g} \mathrm{~L}^{-1}$ active ingredient) applied at a rate of $2 \mathrm{~kg} \mathrm{ha}^{-1}$. Close to the plants the weeds were carefully removed manually with a hoe. The fertilizers applied in the following seasons were spread manually in the previously defined plots and at the rates already described. The plants were also annually pruned by removing a few branches from the lower parts of the plant.

2.3. Field determinations, sampling, and laboratory analysis

During the 4 years of study, stem diameter at $10 \mathrm{~cm}$ aboveground and plant height were determined annually after leaf fall in the autumn. The pruning wood was also weighed fresh and dry, after being sent to the laboratory.

Estimates of chlorophyll content of leaves were recorded by using the portable SPAD-502 Plus chlorophyll meter. Thirty readings per replication were taken from the blades of young fully expanded leaves.

The normalized difference vegetation index (NDVI) was estimated using the Field Scout CM 1000 NDVI meter. The NDVI value ( -1 to 1$)$ is calculated from the measured ambient and reflected light data [(\%Near Infrared \%Red) / (\%Near Infrared + \%Red)]. Readings are taken by pressing a trigger, which activates the targeting lasers, causing the measuring and calculating mechanism to operate. Thirty NDVI readings per replication were taken from the blades of fully expanded young leaves between 1000 and 1100 hours.

The OS-30p+ handheld portable modulated chlorophyll fluorometer was also used. The OS-30p+ fluorometer is designed to measure precisely chlorophyll $a$ fluorescence and transient fluorescence by using dark adaptation protocols for $\mathrm{F}_{\mathrm{V}} / \mathrm{F}_{\mathrm{M}}, \mathrm{F}_{\mathrm{V}} / \mathrm{F}_{0}$, and advanced OJIP measurements. $F_{M}$ and $F_{0}$ are the maximum and minimum fluorescence, respectively, and $\mathrm{F}_{\mathrm{V}} / \mathrm{F}_{\mathrm{M}}=\left(\mathrm{F}_{\mathrm{M}}-\right.$ $\left.\mathrm{F}_{0}\right) / \mathrm{F}_{\mathrm{M}}$ and $\mathrm{F}_{\mathrm{v}} / \mathrm{F}_{0}=\left(\mathrm{F}_{\mathrm{M}}-\mathrm{F}_{0}\right) / \mathrm{F}_{0}$. The OJIP test provides origin fluorescence at $20 \mu \mathrm{s}(\mathrm{O})$, fluorescence at $2 \mathrm{~ms}(\mathrm{~J})$, fluorescence at $30 \mathrm{~ms}(\mathrm{I})$, and maximum fluorescence or $\mathrm{F}_{\mathrm{M}}(\mathrm{P})$. The fluorometer uses a pulse-modulated detection system to allow for a variety of tests, with high capability 
for detecting and measuring plant stress types that affect photosystem II. Measurements were taken from young fully expanded leaves after a period of dark adaptation longer than $35 \mathrm{~min}$. These measurements were taken between 1100 and 1230 hours.

Once a year (28-06-2014, 24-07-2015, 15-07-2016) leaf samples were collected to determine the elemental composition and to evaluate the effect of the treatments on the nutritional status of the plants. The youngest fully expanded leaves were selected for analysis. All tissue samples were dried in an oven at $70^{\circ} \mathrm{C}$ and ground. Tissue analyses were performed by Kjeldahl $(\mathrm{N})$, colorimetry (B and $\mathrm{P})$, flame emission spectrometry $(\mathrm{K})$, and atomic absorption spectrophotometry $(\mathrm{Ca}, \mathrm{Mg}, \mathrm{Cu}, \mathrm{Fe}, \mathrm{Zn}$, and $\mathrm{Mn})$ methods.

Soil samples were taken on 6 January 2017, separated into three layers of depth $(0-5,5-10$, and $10-20 \mathrm{~cm})$, from all the fertilized treatments and blocks. Each field soil sample was a composite sample of four subsamples. The pretreatments of soil samples consisted of oven-drying at $40{ }^{\circ} \mathrm{C}$ and sieving in a mesh of $2 \mathrm{~mm}$. Soil samples were analyzed for organic carbon (Walkley-Black), $\mathrm{pH}_{(\mathrm{H} 2 \mathrm{O})}$, $\mathrm{pH}_{(\mathrm{KCl})}$ (soil:solution, 1:2.5), and cation-exchange capacity (Ca, Mg, K, Na, and exchangeable acidity) (ammonium acetate, $\mathrm{pH}$ 7.0). Extractable $\mathrm{P}$ and $\mathrm{K}$ were determined by ammonium lactate method $\left(\mathrm{P}_{\mathrm{AL}}, \mathrm{K}_{\mathrm{AL}}\right)$. Soil B was extracted by hot water and the extracts analyzed by azomethine- $\mathrm{H}$ method. The availability of other micronutrients in soil $(\mathrm{Cu}, \mathrm{Fe}, \mathrm{Zn}$, and $\mathrm{Mn}$ ) was determined by atomic absorption spectrometry after extraction with ammonium acetate and EDTA.

\subsection{Data analysis}

Data were subjected to analysis of variance (ANOVA). When significant differences between fertilizer treatments were found, the means were separated by Tukey-Kramer HSD test $(\alpha=0.05)$.

\section{Results}

In January 2017 soil samples were collected to assess the effect of liming and the application of fertilizer on several soil properties. Liming significantly increased soil $\mathrm{pH}$ and reduced the availability of Mn (Figure 2). Lime was incorporated into the soil by a single pass with a cultivator, which caused a more pronounced effect in the surface $0-5 \mathrm{~cm}$ soil layer. No other soil property was significantly influenced by liming (data not shown). The annual application of $\mathrm{P}$ or $\mathrm{K}$ significantly increased extractable $\mathrm{P}_{\mathrm{AL}}$ or $\mathrm{K}_{\mathrm{AL}}$, respectively (Figure 2). The upper soil layers showed higher levels of extractable $\mathrm{P}$ and $\mathrm{K}$, probably because these fertilizers were not incorporated into the soil, with the exception of the first application in 2013. The annual application of $\mathrm{N}$ or B did not influence any of the determined soil properties (data not shown).
Four growing seasons after planting, the average height of the young trees varied from 101.4 to $131.6 \mathrm{~cm}$. The treatments with the absence of applications of potassium (NP-KB) or boron (NPK-B) as fertilizers gave the smaller trees (Figure 3). This trend began to be shown from the first measurements in the autumn of 2013.

The increase in trunk diameter of the young trees showed a similar pattern to that observed in the height of the plants. The NP-KB and NPK-B fertilizer treatments displayed the lowest trunk diameters (Figure 4). The nonapplication of $\mathrm{N}$ or $\mathrm{P}$ did not reduce the diameter of the trunk of the young trees in comparison to the treatments where these nutrients were applied.

The amount of dry biomass removed in three pruning events (2014-2016) was significantly lower in the NP-KB and NPK-B treatments in comparison with the LNPKB treatment (Figure 5). In this aspect, the result was similar to that found by measuring the height and the trunk diameter of the plants. However, the dry biomass of prunings of the -NPKB treatment gave signs of also starting to decline, although still without significant differences from the LNPKB treatment, which produced the higher amount of prunings.

The fertilizer treatments with a lack of a given nutrient usually showed lower concentrations of that element in the leaves (Figure 6). On three sampling dates, significant differences in leaf nutrient concentration between fertilized and nonfertilized plots occurred two, one, two, and three times for $\mathrm{N}, \mathrm{P}, \mathrm{K}$, and $\mathrm{B}$, respectively. Significant differences were also found in leaf $\mathrm{Zn}$ and $\mathrm{Mn}$ concentrations between LNPKB and NPKB treatments. No significant differences were found for any other nutrients among the fertilizer treatments (data not shown). Leaf $\mathrm{N}$ and $\mathrm{P}$ concentrations usually were found within or close to the adequate range established for chestnut. Leaf $\mathrm{K}$ concentrations were found in the deficiency range, except on the last sampling date of the treatment receiving $\mathrm{K}$ as a fertilizer. Leaf B concentration was found in the deficiency range in the treatment that did not receive $B$ as a fertilizer. On the second sampling date, the plot receiving $B$ as a fertilizer displayed leaf $\mathrm{B}$ concentration in the excessive range. This result led to the reduction of the rate of $B$ application from 3 to $2 \mathrm{~kg} \mathrm{ha}^{-1}$ (see Section 2). Leaf $\mathrm{Zn}$ and Mn concentrations were always found within the adequate range for these micronutrients.

SPAD values were consistently lower in the -NPKB treatment (Table 2), establishing a clear relationship between leaf greenness and soil available nitrogen. However, the lower leaf greenness of the plants of the NPKB treatment was not enough to produce a reduction in the height and trunk diameter of the trees (Figures 3 and 4). No other treatment caused a consistent effect in 

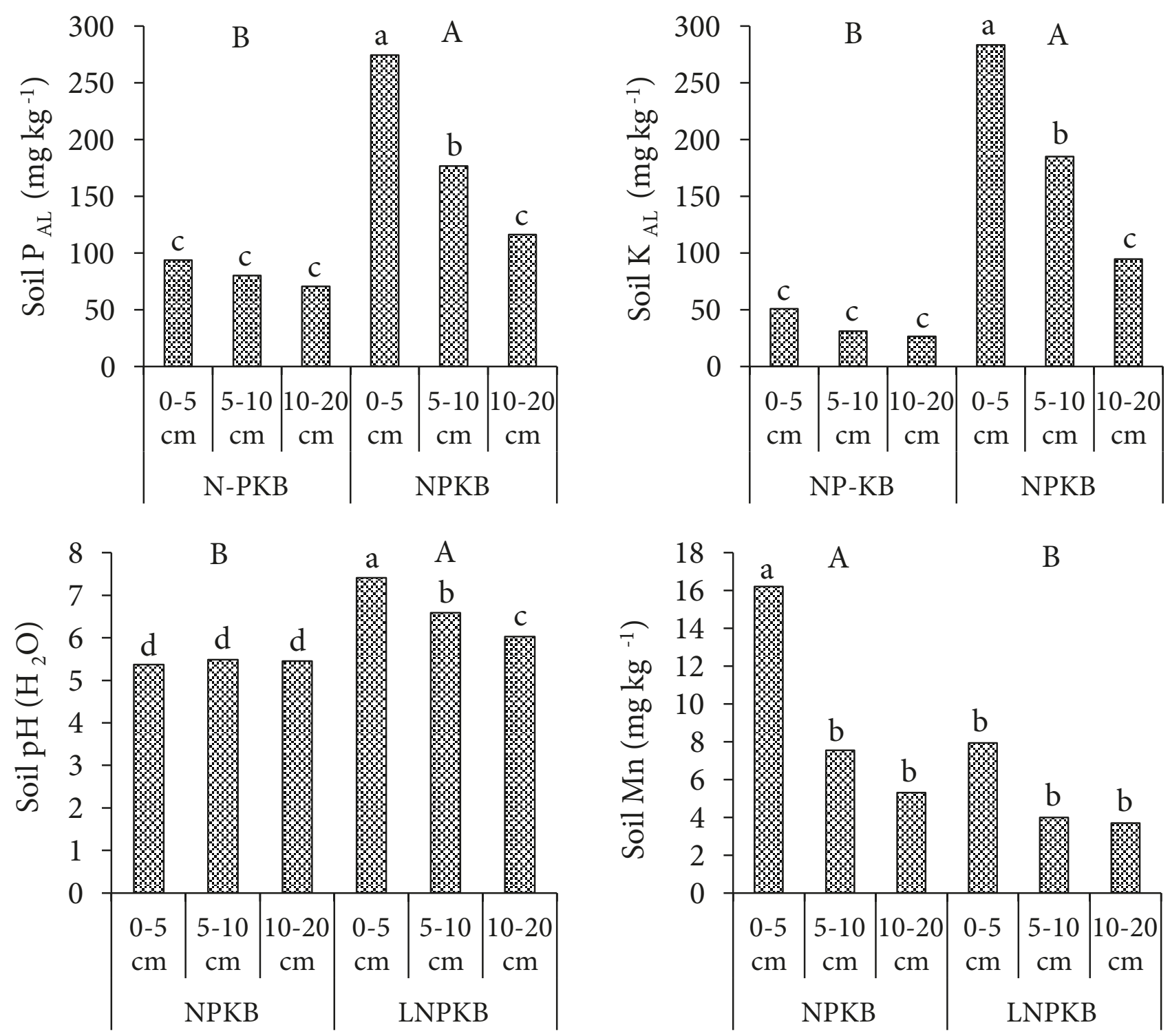

Figure 2. Soil $\mathrm{P}_{\mathrm{AL}}$, soil $\mathrm{K}_{\mathrm{AL}}$, soil $\mathrm{pH}\left(\mathrm{H}_{2} \mathrm{O}\right)$, and soil $\mathrm{Mn}$ at three soil depth layers $(0-5,5-10$, and 10-20 cm) as a function of the fertilizer treatments consisting of the application of lime (L) plus NPKB (LNPKB), NPKB (without lime), and the other three nutrients without P $(\mathrm{N}-\mathrm{PKB})$ or K (NP-KB). Lowercase letters indicate the results of the Tukey HSD test $(\alpha=0.05)$ for each population of soil samples, and upper case letters are the result of the Tukey test for the fertilizer treatments.

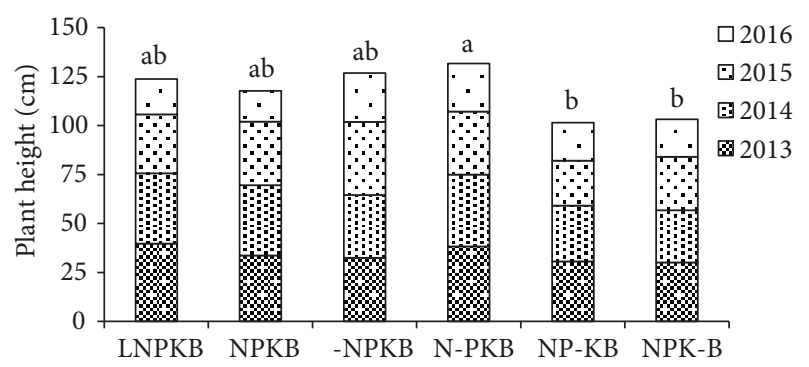

Figure 3. Average annual increase in height of the young chestnut trees in the treatments corresponding to the application of lime (L) plus NPKB (LNPKB), NPKB without lime (NPKB), and the other nutrients without N (-NPKB), P (N-PKB), K (NP-KB), or B (NPK-B). Letters above the columns indicate the results of the Tukey HSD test $(\alpha=0.05)$ for the total height of plants. 


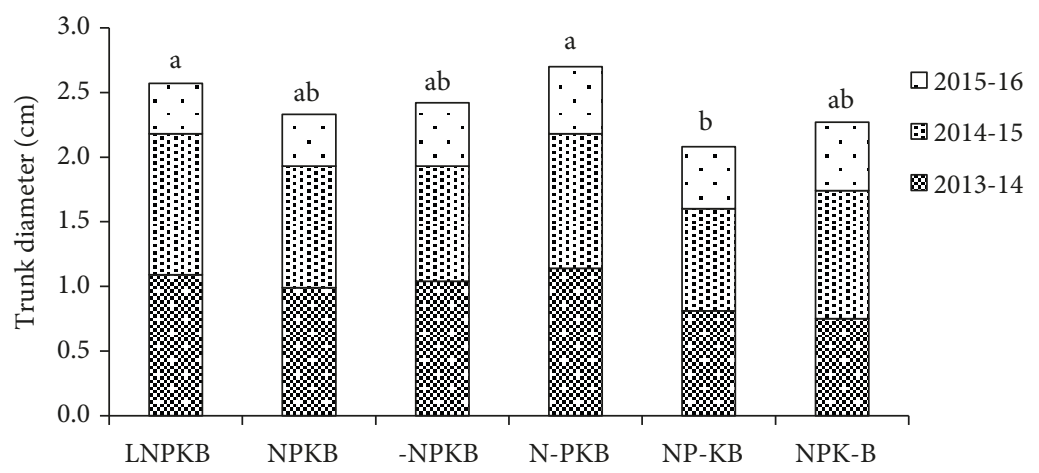

Figure 4. Average annual increase in trunk diameter of the young chestnut trees in the treatments corresponding to the application of lime (L) plus NPKB (LNPKB), NPKB without lime (NPKB), and the other nutrients without N (-NPKB), P (N-PKB), K (NP-KB), or $B(N P K-B)$. Letters above the columns indicate the results of the Tukey HSD test $(\alpha=0.05)$ for the total trunk diameter increase from 2013 to 2016.

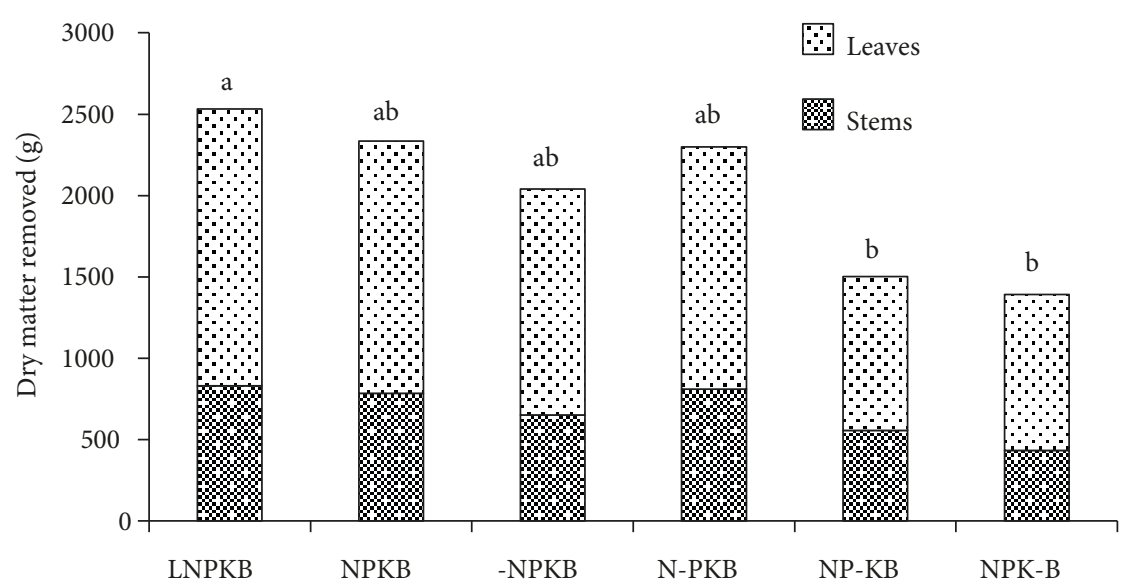

Figure 5. Average sum (2014-2016) of prunings separated into stems and leaves in the treatments corresponding to the application of lime (L) plus NPKB (LNPKB), NPKB without lime (NPKB), and the other nutrients without N (-NPKB), P (N-PKB), K (NP-KB), or $B(N P K-B)$. Letters above the columns indicate the results of the Tukey HSD test $(\alpha=0.05)$ for the total trunk diameter increase from 2013 to 2016 .

the leaf greenness detected by the SPAD-502 chlorophyll meter.

The Field Scout CM 1000 NDVI results were somewhat similar to those of the chlorophyll-SPAD meter. The treatment $-\mathrm{NPKB}$ showed consistently lower values and on some sampling dates they were significantly lower than those of the treatments displaying the higher ones (Table 3).

In spite of several measurements taken using the dark adaptation protocols $\mathrm{F}_{\mathrm{V}} / \mathrm{F}_{\mathrm{M}}, \mathrm{F}_{\mathrm{V}} / \mathrm{F}_{0}$, and advanced OJIP measurements performed by the OS-30p+ fluorometer during the growing seasons of 2014-2016, no significant differences were found among the fertilizer treatments for any of the protocols and sampling dates (Table 4). Not even a consistent trend was noticed for any of the fertilizer treatments.

\section{Discussion}

The application of lime significantly increased soil $\mathrm{pH}$ and reduced soil available Mn. Since lime was incorporated with a single pass of a cultivator, without turning the soil, the effect was marked in the top soil layer and decreasing with depth. The principal species of $\mathrm{Mn}$ in soil solution is $\mathrm{Mn}^{2+}$, which may decrease 100-fold for each unit increase in $\mathrm{pH}$, and is also the main form as $\mathrm{Mn}$ is absorbed by plants (George et al., 2012; Havlin et al., 2014). Thus, the decreased soil $\mathrm{Mn}$ availability also reduced the concentration of the nutrient in chestnut leaves. In this experiment, liming did not cause a significant difference in the levels of $\mathrm{Ca}, \mathrm{Mg}, \mathrm{P}$, and other nutrients in the soil. The application of $\mathrm{P}$ and $\mathrm{K}$ as fertilizers increased the levels of these nutrients in the top soil layer as expected, there being also observed a rapid decrease of the effect with 

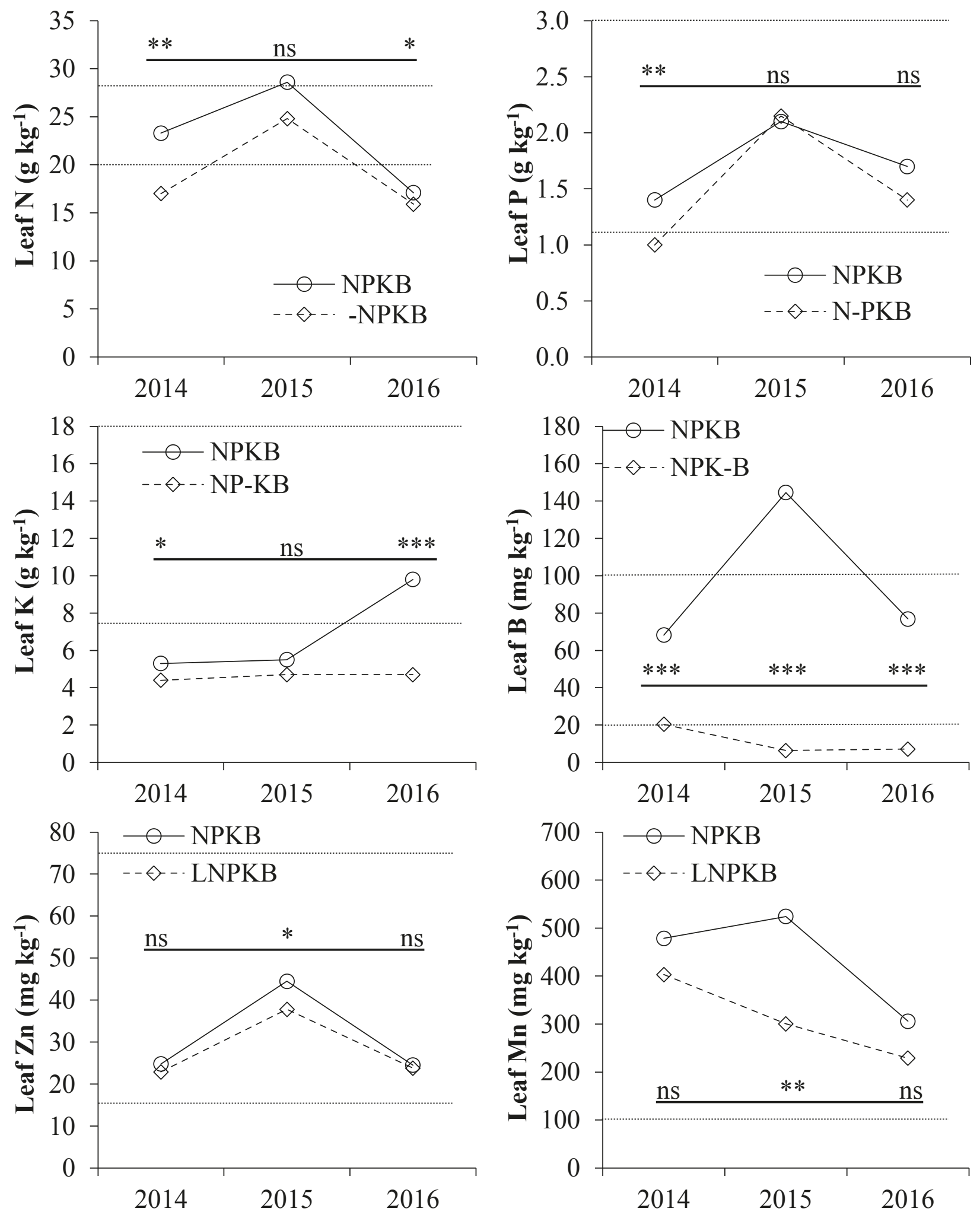

Figure 6. Leaf concentrations of N, P, K, B, Zn, and Mn in three growing seasons (2014-2016) in the treatments corresponding to the application of lime (L) plus NPKB (LNPKB), NPKB without lime (NPKB), and the other nutrients without N (-NPKB), P (N-PKB), K $(\mathrm{NP}-\mathrm{KB})$, or B (NPK-B). ANOVA results are presented as the letters, ns (not significant), and symbols ${ }^{\star}(\mathrm{P}<0.05)$, ${ }^{*}(\mathrm{P}<0.01)$, and $* * \star(P<0.001)$. Horizontal dashed lines define the sufficiency ranges for the nutrient represented in each figure. 
Table 2. SPAD readings taken from six sampling dates of three growing seasons. In each column, means with the same letter are not significantly different by Tukey HSD test $(\alpha=0.05)$.

\begin{tabular}{|l|l|l|l|l|l|l|}
\hline \multirow{2}{*}{$\begin{array}{l}\text { Fertilizer } \\
\text { treatment }\end{array}$} & \multicolumn{4}{|l}{ Sampling date } \\
\cline { 2 - 7 } & 30 May 2014 & 28 June 2014 & 7 August 2014 & 24 July 2015 & 17 July 2016 & 22 August 2016 \\
\hline LNPKB & $25.1 \mathrm{ab}$ & $32.8 \mathrm{a}$ & $39.2 \mathrm{abc}$ & $40.1 \mathrm{ab}$ & $32.6 \mathrm{ab}$ & $35.4 \mathrm{a}$ \\
\hline NPKB & $25.7 \mathrm{ab}$ & $31.5 \mathrm{a}$ & $40.9 \mathrm{a}$ & $37.6 \mathrm{bc}$ & $33.3 \mathrm{ab}$ & $36.3 \mathrm{a}$ \\
\hline- NPKB & $24.2 \mathrm{~b}$ & $27.5 \mathrm{~b}$ & $37.5 \mathrm{~d}$ & $34.2 \mathrm{c}$ & $31.1 \mathrm{~b}$ & $34.2 \mathrm{a}$ \\
\hline N-PKB & $27.6 \mathrm{a}$ & $31.5 \mathrm{a}$ & $40.0 \mathrm{ab}$ & $38.6 \mathrm{ab}$ & $35.3 \mathrm{a}$ & $37.6 \mathrm{a}$ \\
\hline NP-KB & $26.1 \mathrm{ab}$ & $32.1 \mathrm{a}$ & $38.4 \mathrm{bcd}$ & $38.9 \mathrm{ab}$ & $33.1 \mathrm{ab}$ & $35.8 \mathrm{a}$ \\
\hline NPK-B & $26.2 \mathrm{ab}$ & $31.6 \mathrm{a}$ & $37.9 \mathrm{~cd}$ & $41.6 \mathrm{a}$ & $32.8 \mathrm{ab}$ & $36.2 \mathrm{a}$ \\
\hline
\end{tabular}

Table 3. Normalized difference vegetation index (NDVI) taken from four sampling dates of two growing seasons. In each column, means with the same letter are not significantly different by Tukey HSD test $(\alpha=0.05)$.

\begin{tabular}{|c|c|c|c|c|}
\hline \multirow{2}{*}{$\begin{array}{l}\text { Fertilizer } \\
\text { treatment }\end{array}$} & \multicolumn{4}{|l|}{ Sampling date } \\
\hline & 30 May 2014 & 28 June 2014 & 7 August 2014 & 24 July 2015 \\
\hline LNPKB & $0.80 \mathrm{a}$ & $0.84 \mathrm{a}$ & $0.82 \mathrm{a}$ & $0.78 \mathrm{ab}$ \\
\hline NPKB & $0.79 \mathrm{a}$ & $0.83 \mathrm{ab}$ & $0.82 \mathrm{a}$ & $0.76 \mathrm{~b}$ \\
\hline -NPKB & $0.79 \mathrm{a}$ & $0.80 \mathrm{c}$ & $0.80 \mathrm{~b}$ & $0.77 \mathrm{~b}$ \\
\hline $\mathrm{N}-\mathrm{PKB}$ & $0.79 \mathrm{a}$ & $0.84 \mathrm{a}$ & $0.82 \mathrm{a}$ & $0.81 \mathrm{a}$ \\
\hline NP-KB & $0.79 \mathrm{a}$ & $0.84 \mathrm{a}$ & $0.82 \mathrm{a}$ & $0.79 \mathrm{ab}$ \\
\hline NPK-B & $0.80 \mathrm{a}$ & $0.83 \mathrm{~b}$ & $0.81 \mathrm{ab}$ & $0.79 \mathrm{ab}$ \\
\hline
\end{tabular}

Table 4. Ratios of variable fluorescence and maximum fluorescence $\left(\mathrm{F}_{\mathrm{V}} / \mathrm{F}_{\mathrm{M}}\right)$ and variable fluorescence normalized to minimum fluorescence $\left(\mathrm{F}_{\mathrm{V}} / \mathrm{F}_{0}\right)$ in young chestnut plants from the sampling dates of 7 August 2014, 24 July 2015, and 15 July 2016.

\begin{tabular}{|c|c|c|c|c|c|c|}
\hline \multirow{2}{*}{$\begin{array}{l}\text { Fertilizer } \\
\text { treatment }\end{array}$} & \multicolumn{3}{|l|}{$\mathrm{F}_{\mathrm{V}} / \mathrm{F}_{\mathrm{M}}$} & \multicolumn{3}{|l|}{$\mathrm{F}_{\mathrm{V}} / \mathrm{F}_{0}$} \\
\hline & 7 August 2014 & 24 July 2015 & 15 July 2016 & 7 August 2014 & 24 July 2015 & 15 July 2016 \\
\hline LNPKB & 0.78 & 0.82 & 0.78 & 3.48 & 4.70 & 3.53 \\
\hline NPKB & 0.80 & 0.80 & 0.78 & 3.99 & 3.95 & 3.47 \\
\hline -NPKB & 0.76 & 0.82 & 0.77 & 3.18 & 4.70 & 3.43 \\
\hline $\mathrm{N}-\mathrm{PKB}$ & 0.78 & 0.82 & 0.78 & 3.55 & 4.63 & 3.62 \\
\hline NP-KB & 0.76 & 0.81 & 0.78 & 3.20 & 4.35 & 3.51 \\
\hline NPK-B & 0.77 & 0.81 & 0.79 & 3.34 & 4.30 & 3.81 \\
\hline
\end{tabular}

depth since the fertilizers were applied to the soil surface without incorporation, except for the first application. The application of $\mathrm{N}$ and $\mathrm{B}$ as fertilizers did not significantly influence the properties of soil that were examined. No soil property is likely to be significantly influenced in the short term by the addition of $\mathrm{N}$ as a fertilizer, including soil organic matter. Regarding B, the nutrient was applied as borax, which is easily dissolved in soils and quickly available for uptake, but at the same time B can be leached with heavy rains (Shorrocks, 1997), which always occurred in the winter period (Figure 1). 
The treatments consisting of the lack of application of $\mathrm{K}(\mathrm{NP}-\mathrm{KB})$ or B (NPK-B) gave shorter and thinner trees. The amount of prunings was also used in this work as an indicator of the vigor of the trees and the results were also the lowest for the NP-KB and NPK-B treatments. The NPKB treatment also showed a trend of producing fewer prunings than LNPKB, NPKB, and N-PKB treatments. The only research that we found testing the application of a fertilizing product in chestnut was carried out by PérezCruzado et al. (2011). They used ash, containing high amounts of $\mathrm{Ca}, \mathrm{K}$, and $\mathrm{Mg}$ and to a lesser extent $\mathrm{P}$. There was observed an increase in the diameter and height of the trees and also an improvement in the nutritional status of the plants in terms of $\mathrm{K}, \mathrm{Ca}$, and $\mathrm{Mg}$. However, from this experiment, the effect on trees of the individual nutrients contained in ash cannot be assessed.

The trees of the NPKB and -NPKB treatments revealed, respectively, leaf $\mathrm{N}$ concentrations appearing within and below the sufficiency range for chestnut. In 2016, leaf $\mathrm{N}$ levels were low in both treatments, likely due to the heavy rain of April and May (Figure 1) after the application of the fertilizers, which may have caused intense leaching of $\mathrm{N}$. Plants usually respond to the application of $\mathrm{N}$ with an increase of the nutrient in the leaf tissues and yield (Rodrigues et al., 2006, 2011; Centeno and Campo, 2011). However, the level of $\mathrm{N}$ deficiency in the -NPKB treatment would not have been severe enough to produce a significant reduction in tree crop growth. Leaf $P$ was usually found within the adequate range in both NPKB and N-PKB treatments. This may explain the lack of plant response to $\mathrm{P}$ applications, in spite of the soil $\mathrm{P}_{\mathrm{AL}}$ levels at the beginning of the experiment being found to be low. Leaf $\mathrm{K}$ levels were always found in the deficient range, except on the sampling date of 2016 of the $\mathrm{NP}-\mathrm{KB}$ treatment. This result may justify the depression of tree growth in NP-KB treatments in comparison with treatments where $\mathrm{K}$ was applied as a fertilizer. The initial results of soil $\mathrm{K}_{\mathrm{AL}}$ levels did not anticipate this result, since they indicated that the soil would be classified as medium. It is possible that the lack of moisture in the soil during the growing period could have limited $\mathrm{K}$ uptake by the roots (Restrepo-Diaz et al., 2008) or that $\mathrm{K}_{\mathrm{AL}}$ is a poor predictor of soil $\mathrm{K}$ bioavailability. Leaf $\mathrm{B}$ was found in the deficiency range in the NPK-B treatment. In the $B$ fertilized plots, leaf B levels were found to be in the excessive range in 2015. After this sampling date the rate of $\mathrm{B}$ application was reduced to $2 \mathrm{~kg} \mathrm{ha}^{-1}$ year $^{-1}$ to reduce the risk of B toxicity. Leaf B levels clearly explain the decreased growth of chestnut in the NPK-B treatment. There is a set of studies in this region showing B deficiency in the leaf and crop response to applied $\mathrm{B}$, both in chestnut (Portela et al., 2011, 2015a) and in olive (Arrobas et al., 2010; Rodrigues et al., 2011). Leaf $\mathrm{Zn}$ and Mn were significantly lower in LNPKB in comparison with NPKB treatments on some sampling dates. However, all the results were found within the adequate ranges for these nutrients, which certainly explains the absence of a significant effect on tree performance in the LNPKB treatment. The six fertilizer treatments did not produce significant differences in leaf concentrations of any other nutrient.

SPAD readings were lower in the $-\mathrm{NPKB}$ treatment. The poor performances of the young trees subjected to the lack of $\mathrm{K}$ or $\mathrm{B}$ applications as fertilizers were not detected by SPAD readings. SPAD readings are usually used as an $\mathrm{N}$ nutritional index, due to the relationship of leaf $\mathrm{N}$ with the greenness or leaf chlorophyll content of the leaves (Rodrigues et al., 2006; Mahajan et al., 2014; Basyouni et al., 2015; Arrobas et al., 2016). The measurements with the SPAD-502 chlorophyll meter showed a reduction in the leaf greenness of the leaves in the -NPKB treatment but this will not have been enough to significantly reduce the height and the trunk diameter of the young trees.

The NDVI gave a result with a similar trend to that of SPAD readings with the lower values associated with the -NPKB treatment. The NDVI was also not able to detect the $\mathrm{K}$ and $\mathrm{B}$ deficiencies, which caused a reduction in the growth of the young trees. This is one index that has also been found associated with the greenness and leaf $\mathrm{N}$ concentration of the leaves (Murdock et al., 2004; Mahajan et al., 2014; Rodrigues et al., 2017).

The dark adaptation protocols, $\mathrm{F}_{\mathrm{V}} / \mathrm{F}_{\mathrm{M}}, \mathrm{F}_{\mathrm{V}} / \mathrm{F}_{0}$, and advanced OJIP measurements, performed by the OS$30 \mathrm{p}+$ fluorometer, were not able to detect $\mathrm{N}, \mathrm{K}$, or $\mathrm{B}$ deficiencies in the leaves even if the two former had reduced the performance of the young trees. Probably this lack of significant differences was due to the fact that these protocols are not sensitive to nutrient stress until very low levels are reached (Baker and Oxborough, 2004), although they can be very useful for detecting and measuring other plant stresses, such as drought (Gomes et al., 2012), high irradiance, and extreme temperatures (Dinis et al., 2016).

In conclusion, liming a soil with initial $\mathrm{pH}$ of $5.5 \mathrm{did}$ not significantly influence tree crop growth, showing that chestnut might be a tolerant crop to moderate soil acidity. The treatments NP-KB and NPK-B gave shorter trees with thinner trunks, which made $\mathrm{K}$ and $\mathrm{B}$ the most limiting nutrients for chestnut growth under the conditions of this experiment. In these treatments, leaf $\mathrm{K}$ and $\mathrm{B}$ were respectively found in the deficiency range of each nutrient. The result was not expected since initial soil $\mathrm{K}$ levels were found to be at a medium level. Leaf $\mathrm{N}$ was found oscillating below and above the lower limit of the adequate range in the $-\mathrm{NPKB}$ treatment, giving the indication that $\mathrm{N}$ was the third most limiting nutrient in this experiment. SPAD readings and the NDVI were able to diagnose the low soil $\mathrm{N}$ availability in the $-\mathrm{NPKB}$ treatment but not the 
decreased growth of the trees associated with the NP-KB and NPK-B treatments. The dark adaptation protocols of $\mathrm{F}_{\mathrm{V}} / \mathrm{F}_{\mathrm{M}}, \mathrm{F}_{\mathrm{V}} / \mathrm{F}_{0}$, and the advanced OJIP measurements failed to diagnose any of the nutrient stresses detected by leaf analysis and growth reduction.

\section{References}

Afif-Khouri E, Álvarez-Álvarez P, Fernández-López MJ, OliveiraPrendes JA, Cámara-Obregón A (2011). Influence of climate, edaphic factors and tree nutrition on site index of chestnut coppice stands in north-west. Forestry 84: 385-396.

Arrobas M, Aguia P, Rodrigues MA (2016). A comparison of a pasture ley with a maize monoculture on the soil fertility and nutrient release in the succeeding crop. Arch Agron Soil Sci 62: 829-839.

Arrobas M, Lopes JI, Pavão F, Cabanas JE, Rodrigues MA (2010). Comparative boron nutritional diagnosis for olive based on July and January leaf samplings. Commun Soil Sci Plant Anal 41: 709-720.

Baker NR, Oxborough K (2004). Chlorophyll fluorescence as a probe of photosynthetic productivity. In: Papageorgiu GC, Govindgee, editors. Chlorophyll Fluorescence: Signature of Photosynthesis. Dordrecht, the Netherlands: Springer, pp. 6679.

Basyouni R, Dunn BL, Goad C (2015). Use of nondestructive sensors to assess nitrogen status in potted poinsettia (Euphorbia pulcherrima L. (Willd. ex Klotzsch)) production. Sci Hortic 192: 47-53.

Centeno A, Campo MG (2011). Response of mature olive trees with adequate leaf nutrient status to additional nitrogen, phosphorus and potassium fertilization. Acta Hort 888: 277-280.

Dinis LT, Ferreira H, Pinto G, Bernardo S, Correia CM, MoutinhoPereira J (2016). Kaolin-based, foliar reflective film protects photosystem II structure and function in grapevine leaves exposed to heat and high solar radiation. Photosynthetica 54: 47-55.

El Kohen A, Rouhier H, Mousseau M (1992). Changes in dry weight and nitrogen partitioning induced by elevated $\mathrm{CO} 2$ depend on soil nutrient availability in sweet chestnut (Castanea sativa Mill). Ann Sci For 49: 83-90.

George E, Horst WJ, Neumann E (2012). Adaptation of plants to adverse chemical soil conditions. In: Marschner P, editor. Marschner's Mineral Nutrition of Higher Plants. London, UK: Academic Press, pp. 409-437.

Gomes MTG, Luz AC, Santos MR, Batitucci MCP, Silva DM, Falqueto AR (2012). Drought tolerance of passion fruit plants assessed by the OJIP chlorophyll a fluorescence transient. Sci Hortic 142: 49-56.

Gouveia ME, Choupina A, Coelho V, Monte E, Hermosa R, Abreu CG (2005). Diagnosis of ink disease of chestnut by molecular identification of associated Phytophthora species. Acta Hortic 639: 585-589.

\section{Acknowledgment}

The authors are grateful to the Foundation for Science and Technology (FCT, Portugal) and FEDER under Programme PT2020 for financial support to CIMO (UID/ AGR/00690/2013).

Havlin JL, Tisdale SL, Nelson WL, Beaton JD (2014). Soil Fertility and Fertilizers: An Introduction to Nutrient Management. 8th ed. Boston, MA, USA: Pearson.

Laroche A, Freyssac V, Rahmani A, Verger JP, Morvan H (1997). Growth and mineral content of young chestnut trees under controlled conditions of nutrition. Ann Sci For 54: 681-693.

Mahajan GR, Pandey RN, Kumar D, Datta SC, Sahoo RN, Parsad R (2014). Development of critical values for the leaf color chart, SPAD and FieldScout CM 1000 for fixed time adjustable nitrogen management in aromatic hybrid rice (Oryza sativa L.). Commun Soil Sci Plant Anal 45: 1877-1893.

Maurel M, Robin C, Capron G, Desprez-Loustau ML (2001). Effects of root damage associated with Phytophthora cinnamomi on water relations, biomass accumulation, mineral nutrition and vulnerability to water deficit of five oak and chestnut species. For Path 31: 353-369.

Murdock L, Call D, James J (2004). Comparison and Use of Chlorophyll Meters on Wheat (Reflectance vs. Transmittance/ Absorbance). Lexington, KY, USA: Cooperative Extension Service, University of Kentucky College of Agriculture.

Pérez-Cruzado C, Solla-Gullon F, Merino A, Rodriguez-Soalleiro R (2011). Analysis of growth and nutrition of a young Castanea $\times$ coudercii plantation after application of wood-bark ash. Eur J Forest Res 130: 209-217.

Portela E, Ferreira-Cardoso JV, Louzada JL (2011). Boron application on a chestnut orchard: effect on yield and quality of nuts. J Plant Nutr 34: 1245-1253.

Portela E, Ferreira-Cardoso J, Louzada J, Gomes-Laranjo J (2015a). Assessment of boron application in chestnuts: nut yield and quality. J Plant Nutr 38: 973-987.

Portela E, Louzada JL (2012). Early diagnosis of boron deficiency in chestnut. J Plant Nutr 35: 304-310.

Portela E, Martins A, Pires AL, Raimundo F, Marques G (2007). Cap 6 - Práticas culturais no souto: o manejo do solo. In: GomesLaranjo J, Ferreira-Cardoso J, Portela E, Abreu CG, editors. Castanheiros. Vila Real, Portugal: Programa AGRO 499, Universidade de Trás-os-Montes e Alto Douro, pp. 207-264 (in Portuguese).

Portela E, Pires CC, Louzada J (2010). Magnesium deficiency in chestnut groves: the influence of soil manganese. J Plant Nutr 33: $452-460$.

Portela E, Roboredo M, Louzada J (2003). Assessment and description of magnesium deficiencies in chestnut groves. J. Plant Nutr 26: 503-523. 


\section{ARROBAS et al. / Turk J Agric For}

Portela E, Vale R, Abreu MM (2015b). Carências de boro no interior - norte e centro - de Portugal. Rev Cienc Agrar 38: 484-517 (in Portuguese).

Restrepo-Diaz H, Benlloch M, Navarro C, Fernández-Escobar R (2008). Potassium fertilization of rainfed orchards. Sci Hortic 116: 399-403.

Rodrigues MA, Afonso S, Ferreira IQ, Arrobas M (2017). Response of stevia to nitrogen fertilization and harvesting regime in Northeastern Portugal. Arch Agron Soil Sci 63: 626-637.
Rodrigues MA, Pavão F, Lopes JI, Gomes V, Arrobas M, MoutinhoPereira J, Ruivo S, Cabanas JE, Correia CM (2011). Olive yields and tree nutritional status during a four year period without nitrogen and boron fertilization. Commun Soil Sci Plant Anal 42: 803-814.

Rodrigues MA, Pereira A, Cabanas JE, Dias L, Pires J, Arrobas $M$ (2006). Crops use-efficiency of nitrogen from manures permitted in organic farming. Eur J Agron 25: 328-335.

Shorrocks VM (1997). The occurrence and correction of boron deficiency. Plant Soil 193: 121-148. 